\title{
An outline of the problem of pelvic organ prolapse, including dietary and physical activity prophylaxis
}

Zarys problemu wypadania narządów miednicy z uwzględnieniem profilaktyki dietetycznej

i aktywności fizycznej

\section{Magdalena Pisarska-Krawczyk ${ }^{\oplus}$, Grażyna Jarząbek-Bielecka² ${ }^{\oplus}$, Małgorzata Mizgier ${ }^{\circledR}$, Katarzyna Plagens-Rotman ${ }^{4} \odot$, Zbigniew Friebe ${ }^{2} \odot$, Witold Kędzia ${ }^{2}$}

'Kaliska Academy im. President Stanislaw Wojciechowski/Akademia Kaliska 2Department of Perinatology and Gynecology, Poznan University of Medical Sciences/ Klinika Ginekologii Katedry Perinatologii i Ginekologii, Uniwersytet Medyczny im. Karola Marcinkowskiego w Poznaniu

${ }^{3}$ Poznań University of Physical Education/Akademia Wychowania Fizycznego w Poznaniu ${ }^{4}$ Hipolit Cegielski State University of Applied Sciences/Państwowa Wyższa Szkoła Zawodowa w Gnieźnie

\section{Katarzyna Plagens-Rotman \\ Państwowa Wyższa Szkoła Zawodowa w Gnieźnie ul. Ks. Kard. S. Wyszyńskiego, 38 62-200 Gniezno e-mail: plagens.rotman@gmail.com}

CORRESPONDING AUTHOR:

\section{AKTYWWOŚCI FIZYCZNE:}

Wprowadzenie. W ginekologii ważną rolę odgrywa właściwy dobór metod diagnostycznych i terapeutycznych, w tym zabiegów zachowawczych i/lub chirurgicznych. Zarys tych zagadnień przedstawiono w kontekście zaburzeń statycznych żeńskich narządów płciowych. Okresem życia kobiety predysponującym do wypadania narządów miednicy jest menopauza, a zwłaszcza okres starości, który wiąże się z hipoestrogenizmem.

Analiza czynników wpływających na ryzyko wystąpienia zaburzeń statyki narządów płciowych wskazuje, że w profilaktyce zaburzeń statycznych narządów płciowych istotne znaczenie mają ćwiczenia dna miednicy oraz odpowiednia dieta, która nie prowadzi do zaparć czy otyłości.

Cel pracy. Celem pracy jest analiza problemu zaburzeń statyki narządów płciowych, istotnego w pielęgniarstwie i medycynie, w świetle danych literaturowych.

Słowa kluczowe: ginekologia, profilaktyka, chirurgia, cystocoele

\section{ABSTRACT}

\section{AN OUTLINE OF THE PROBLEM OF PELVIC ORGAN PROLAPSE, INCLUDING DIETARY AND PHYSICALACTIVITY}

\section{PROPHYLAXIS}

Introduction. In gynecology, the proper selection of diagnostic and therapeutic methods, including conservative and/or surgical procedures, plays an important role. An outline of these issues is presented in the context of static disorders of female genital organs. The period of a woman's life predisposing to pelvic organ prolapse is menopause, especially the period of senium, which is associated with hypoestrogenism. An analysis of the factors affecting the risk of disorders of genital statics indicates that pelvic floor exercises and a proper diet, which does not lead to constipation or obesity, are important in the prevention of genital static disorders.

Aim. The aim of the study is to analyze the problem of disorders of the statics of genital organs, which is significant in nursing and medicine, in the light of the literature data.

Key words:

$$
\text { gynecology, prevention, surgery, cystocoele }
$$




\section{INTRODUCTION}

Although in the era of the pandemic, the fight against SARS-CoV-2 coronavirus infections is a priority (Covid 19 in this context), one of the most important medical and nursing problems are geriatric issues - issues related to the aging of societies [1-6].

More than $11 \%$ of the total population are people over the age of 65 , this percentage will increase to $13 \%$ by 2020; secondly, we live longer - a 65-year-old man easily reaches the age of 79 , and a woman even 83 years. The more people there are, the more attention should be paid to them in terms of their health, also in terms of sexual health [1-2,4-6].

One of the most important problems in anti-aging medicine, gynecology and sexology are disorders of the statics of the female genital organs, usually resulting in sexual dysfunction and urogynecological problems.

Pelvic floor dysfunction increases with age. The period of a woman's life predisposing to pelvic floor dysfunction is menopause, especially the period of senium, which is associated with hypoestrogenism.

The balance of forces operating in the pelvis determines the proper position of the female genitals. Regardless of their location in the human body, the structures responsible for the correct anatomical relations are bones, ligaments, tendons, fasciae and muscles. The forces, i.e. gravity, that produce stretching are risk factors for pelvic organ prolapse during the individual's lifespan.

- An analysis of factors influencing the risk of pelvic floor dysfunction indicates that physical activity (pelvic floor exercises) is important in prophylaxis, as is a proper diet, which reduces the risk of constipation and excessive body weight, at the same time, taking into account the increased catabolism during especially senium period [7-10].

- Lowering or prolapse of the uterus and vagina, and secondary incontinence may be caused by the following:

- pelvic floor failure,

- weakening of the suspension and support apparatus,

- abdominal pressure disorders with visceral prolapse, which is due to the weakening of the pelvic floor, a falling, hanging abdomen, separation of straight muscles, and possibly a slight asthenic body structure,

- it is emphasized that significant factors for a lowering and prolapse of the genitals are:

- perinatal damage to tissues,

- flaccidity of ligaments and coercion, pelvic floor muscledamage.

However, additional causative factors were diseases with persistent cough, strenuous manual work and stress, being overweight or obese, and having chronic constipation. It is worth emphasizing that some factors in pelvic floor dysfunction can be prevented by introducing the appropriate lifestyle and nutrition, for instance, obesity, being overweight and constipation, especially when habitual [10-19].

\section{AIM}

The aim of the study is to analyze the problem of disorders of the statics of genital organs, which is significant in nursing and medicine, in the light of the literature data.

\section{Types of disorders of activity pelvic floor disorders}

Female pelvic floor dysfunction can be divided into structural disorders, which result in their lowering of the genitals or prolapse, and functional disorders. There is a close relationship between structure and function, so functional disorders result from connective tissue structure disorders. The bottom of the pelvis is formed by organs (bladder, vagina and rectum) that stabilize the fascia and ligaments, and the muscles. In simple terms, it can be said that contracting muscles stabilize the organs relative to connective tissue elements. Hence, damage to the ligaments and connective tissue results in a lack of proper closure (incontinence) or incorrect function (vagina), and thus, discomfort reported by patients. The list below contains the disease entities that occur due to pelvic floor dysfunction [11].

Urinary incontinence. The simplest definition of the disease is to lose urine independently of will. The incidence of urinary incontinence increases with age in the female population studied and ranges from 10 to $60 \%$. The main forms of the disease are exercise-type and urgent-type. Surgical treatment is only possible in stress urinary incontinence, while urge and mixed incontinence is treated pharmacologically or with behavioral therapy. Due to side effects, long-term pharmacological treatment is troublesome for patients and is poorly tolerated [12].

\section{Pollakiuria}

This is defined as the number of voids per day greater than eight. The causes of pollakiuria are usually not known. The disorder is treated medically and through bladder training. These methods often prove ineffective, especially with prolonged use.

\section{Nocturia}

It is more than two voids during the hours of night-time rest. As in the case of pollakiuria, it was not possible to find out the causes of nocturia and to develop effective methods for therapy [12].

\section{Intestinal disorders}

These consist of two main elements - problems with emptying the intestine (constipation) and excessive flatulence or incontinence. Stool incontinence may be caused by damage to the anal sphincter and pelvic floor muscles. The incidence of bowel dysfunction in women is between 10 and $20 \%$. The methods used to treat this disorder, such as medication that slows bowel function, diet and levator anal surgery, have been used with limited success.

\section{Impaired emptying of the bladder}

The dominant symptom may be chronic inflammation resulting from significant retention of urine. Although 
there is no obstacle to the outflow of urine, the treatment uses ineffective surgery to widen the urethra.

\section{Chronic pelvic pain}

This occurs in up to $20 \%$ of women. Patients report a unilateral and persistent pulling sensation of varying intensity. The cause of the ailment remains unknown, but psychological factors cannot be excluded.

\section{Causes and other important issues of pelvic floor dysfunction}

Pelvic floor dysfunction is mainly caused by damage to the connective tissue of the vagina and stabilizing ligaments. Therapeutic premises arising from integral theory are based on the principle that restoration of the correct structure ensures that proper function returns to the organ. Therefore, repairing damaged ligaments and fascia creates the possibility of treating many of the above-mentioned conditions, which were previously considered incurable using traditional methods.

The correctness of anatomical structures ensures they function properly. Dysfunction is an abnormal function in an organ or system resulting from damage to its structure. Interestingly, not all patients with pelvic floor dysfunction report clinical symptoms. The cause of most cases of vaginal, bladder and uterine depression or prolapse is perinatal injury. Age and congenital disorders of collagen metabolism also play an important role. Even at rest, maintaining vaginal wall tension is necessary for the proper function of the urethral sphincter and for stabilizing the position and thus, the function of stretch sensitive receptors. One of the important issues related to pelvic floor disorders strongly affecting sexual functioning is the lowering of the vaginal walls. Lowering the front wall also results in urological problems.

Lowering the front wall of the vagina is called cystocoele. Depending on the episode in which there is a decrease, we are talking about cystocoele, urethrocoele and cystourethrocoele [1].

Richardson distinguished four defects responsible for lowering the anterior vaginal wall depending on the etiopathomechanism of the cystocoele:

- side defect,

- transverse defect,

- central defect,

- distal defect.

A lateral defect is the detachment of the pubic-cervical fascia from the place of its attachments, i.e. the tendon arch of the pelvic fascia. The result of this defect is the formation of cystourethrocoele, loss of the tubo-bullous angle, excessive mobility of the urethra, and significant incontinence. Loss of vaginal lateral suspension may occur on one or both sides [13].

Transverse defects account for about $15 \%$ of all cases of anterior depression of the vaginal walls. It often coexists with the loss of side suspension. It involves detachment of the pubic-cervical fascia from the peri-cervical fibrous ring. Its effect is the formation of a significant degree of cystocoele, including the Retzius bay. The coexistence of stress urinary incontinence and this type of cystocoele is rare. In advanced cases, urine retention is often observed.

A central defect refers to the middle segment of the pelvic fascia located between the anterior vaginal wall and the bladder and/or the urethra. Depending on the extent of this defect, cysto- or urethrocele develops. If pelvic fascia damage is at the level of the bladder neck, the result might be a loss of the tubular-bladder angle and stress urinary incontinence.

A distal defect arises as a result of damage (weakening or rupture) to the pubic-urethral ligament. It is the rarest defect and the most difficult to correct. Its clinical manifestation is increased urinary incontinence.

Cystocoele is a manifestation of four defects: distal, central, lateral and transverse. These defects can occur separately or in parallel.

1. Cystocoele may coexist with other static and other genital disorders. Cystocoele correction must be combined with the treatment of other pelvic floor disorders and other conditions. This determines the choice of operational access. Defects included in the static disorders of the anterior vaginal wall are treated by various methods. In practice, single (isolated) defects rarely occur. This forces medical practitioners to look for therapeutic methods that correct all co-existing ones disorder. Generally speaking, the goal of surgical treatment of pelvic fascia defects regarding the front wall of the vagina is: to correct cystocoele and/or urethrocoele itself,

2. to correct other static disorders,

3. to prevent iatrogenic statics disorders,

4. to treat stress urinary incontinence,

5. to treat other gynecological diseases.

Treatment methods for cystocoele can be divided depending on:

1. the corrected system,

2. access applied,

3. the technique used.

\section{Ad.1. Correction may relate to:}

- the support system - a typical example is the Kelli method of duplication of the vesico-vaginal fascia,

- the pancreatic system - typical examples are colpopexy or vaginal suspensions.

Ad.2. Cystocoele operations may be performed from the vascular or vaginal access. The vascular access is suitable for correcting lateral and distal defects. A lateral defect corrects by suturing the vagina to the lateral defect repair (LDR) or to the fascia of the internal vein muscle (Hirsch method). A distal defect corrects for Burch surgery or surgery to correct a lateral vaginal suspension defect with sutures on the tubo-pelvic ligaments [14]. Vaginal access can also be used to correct the loss of side suspension [5]. However, due to technical difficulties involved, this operation is not widely accepted.

Ad. 3. Corrective cystocoele operations can be performed using the classical technique with sutures or synthetic meshes [7], or materials of biological origin, such as Pelvicol [8]. 
The next groups of procedures are needle operations namely surgery using the Pereyra method, surgery using the Raz method, and voltage-free techniques with the use of tapes (Intra Vaginal Sling-IVS, Tension-free Vaginal Tape-TVT, Trans Obturator Tape - TOT) [15]. Static disorder corrective surgery can also be performed using the laparoscopic technique. This has been used in the treatment of distal and lateral defects. Laparoscopic Burch surgery retains the idea of the original method, i.e. the same hanging elements and the same anchoring structure arise from endoscopic surgical techniques and consist of the production of pneumothorax (intraperitoneal or peritoneal), the use of specific instruments and the use of different methods of attachment (e.g. synthetic meshes, staplers). Laparoscopic bladder neck suspension using the Burch method seems to have similar effectiveness in treating stress urinary incontinence [14]. However, the distant effects of laparoscopic vaginal suspension have not been studied thoroughly. Laparoscopic correction of the lateral vaginal suspension defect is one of the most difficult techniques (long time of surgery, very good laparoscopic training required) and can be used in a narrow group of patients. Treatment of concomitant internal genital disorders (fibroids, ovarian tumors, etc.) requires the opening of the peritoneal cavity. Hence, onset is the "gold standard" for lateral defect treatment. However, after an initial period of popularity, the laparoscopic method is now used less and less often. This was significantly affected by the turbulent development of simpler voltage-free techniques that were easier to perform. Laparoscopy, on the other hand, allows obliteration of the pouch of Douglas, on condition that transpaperitoneal access is selected. Stress urinary incontinence accompanies distal and lateral defect (in some patients). Voltage-free suspensions of the vagina and urethra, as well as Burch surgery, are standard in these cases. According to some authors, correcting a lateral vaginal suspension defect is a good treatment method not only for the loss of lateral suspension but also for accompanying stress urinary incontinence [16]. According to Mart [15], in cases of lateral defect and stress urinary incontinence, reconstruction of the lateral suspension of the vagina can be used in parallel with Burch sutures. The choice of surgical technique must take into account the risk of iatrogenic static disorders such as cervical elongation or secondary rectocoels or enterocele caused by the displacement of the long vaginal axis with the exposure of the posterior wall of the vagina to the abdominal compressor. In such cases, the cervix should be amputated appropriately and obliteration of the pouch of Douglas and posterior plastic should be used.

Front access allows central and transverse defect correction.

Theoretically, lateral and distal defects can be corrected by laparoscopic access (laparoscopic lateral defect correction and laparoscopic Burch surgery respectively). The former technique is difficult and is reserved for very skilled operators [17].

To sum up, cysteole is a manifestation of four defects: distal, central, lateral and transverse. These defects can occur separately or in parallel, and can coexist with other static disorders and other genital diseases. Cystocoele correction must be combined with the treatment of other static disorders, which determines the choice of surgical access.

\section{Dietary and physical activity prophylaxis}

The factors affecting the risk of pelvic floor dysfunction are being overweight and obesity, and constipation, especially when it is habitual. These can be prevented by introducing the proper lifestyle and nutrition. Therefore, it is important that a patient at risk of genetic disorders, in particular being overweight or obese or/and complaining of habitual constipation, is referred by a gynecologist to a qualified dietitian for dietary therapy.

In dietotherapy, it is important to increase the amount of dietary fiber (in particular its insoluble form) and oligosaccharides with prebiotic properties. It is also important to drink the right amount of fluids, to include fermented dairy products, in particular those containing probiotic bacteria, and to reduce the consumption of fatty products and sweets $[18,19]$.

Probiotics are widely used to improve gastrointestinal (GI) health, but they may also be useful in preventing or treating gynaecological disorders [20-26].

The gut microbiome can influence the energy balance and is a major site of small molecule production, which can influence satiety and gut inflammation [27].

Meals should be eaten regularly, preferably 4-5 meals a day at 3-4 hours intervals. In the prevention of genital statics disorders, it is important that in the morning there is an increase in motor and excretory activities of the gastrointestinal tract, therefore an important meal during the day is an easily digestible but nutritious breakfast [18].

In order to increase the amount of fiber and prebiotic ingredients, the diet should contain whole grains (coarse cereals, whole grain bread, wheat bran, oatmeal) and appropriate amounts of vegetables and fruits (in particular berries, such as raspberries, strawberries and blackberries) [18-20, 27-28].

In addition to diet, a very important issue is prevention, including appropriate activity [29-30].

Utilizing recent research concerning dynamics of pelvis and pelvic floor dysfunction, it is now possible to study this important body part as a unit.

This means considering its contribution to the whole body, in which maintaining an upright position, walking and behavior or physical conduct are as important as urinary, genital and intestinal functions.

It is now possible to consider the pelvic floor as a musculofascial unit with synergic and antagonistic activity of muscular bundles, among them more or less interlaced, with multiple functions and not only the function of pelvic cup closure [23].

One of the proposed treatments for pelvic floor dysfunction is pelvic floor physical therapy (PFPT). PFPT is a first-line conservative treatment option for pelvic floor disorders.

Pelvic floor dysfunction can cause voiding and defecation problems, pelvic organ prolapse (POP), sexual 
dysfunction, and pelvic pain. PFPT is a program of functional retraining to improve pelvic floor muscle strength, endurance, power, and relaxation in patients with pelvic floor dysfunction. Based on the available evidence, PFPT with or without supplemental modalities, can improve or cure symptoms of urinary incontinence, POP, fecal incontinence, peripartum and postpartum pelvic floor dysfunction, and hypertonic pelvic floor disorders, including pelvic floor myofascial pain, dyspareunia, vaginismus, and vulvodynia.

PFPT has robust evidence-based support and clear benefits as a first-line treatment for most pelvic floor disorders. However, standards of PFPT treatment protocols vary widely and larger-scale, well-designed trials are recommended to show long-term effectiveness [29].

\section{SUMMARY}

A review of the literature reveals significant progress in surgical treatment methods in gynecology. These methods contribute to women's functioning properly in the sexual sphere as well, which particularly applies to surgery of pelvic floor disorders [1,18]. Prevention, including the proper diet, appropriate physical activity and physiotherapy, is also a very important issue.

\section{ORCID}

Magdalena Pisarska-Krawczyk (iD) https://orcid.org/0000-0001-9050-6694 Grażyna Jarząbek-Bielecka (iD https://orcid.org/0000-0003-1385-5641 Małgorzata Mizgier (D) https://orcid.org/0000-0002-9533-2950

Katarzyna Plagens-Rotman (iD https://orcid.org/0000-0001-7646-7430 Witold Kędzia (iD https://orcid.org/0000-0001-9905-0857

\section{REFERENCES}

1. Jarząbek-Bielecka G, Madziar K, Bojanowska K, et al. The outline of the problem of suffering and pain in GP practice. Selected medical and humanistic aspects also in the context of the coronavirus pandemic. Med. Rodz. 2020; 23: 22-25.

2. Jarząbek-Bielecka G, Wilczak M, Potasińska-Sobkowska A, et al. Overweight, obesity and female sexuality in perimenopause: a preliminary report. Prz. Menopauz.: 2015; 2: 97-104.

3. Morling JR, McAllister DA, Agur W, et al. Adverse events after first, single, mesh and non-mesh surgical procedures for stress urinary incontinence and pelvic organ prolapse in Scotland, 1997-2016: a population-based cohort study. Lancet. 2017; 11; 389(10069): 629-640.

4. Liang CC, Lo TS, Tseng LH, et al. Sexual function in women following transvaginal mesh procedures for the treatment of pelvic organ prolapse. Int. Urogynecol. J. 2012; 23(10):1455-1460.

5. Jarząbek-Bielecka G, Buks J, Witkowska J, i wsp. Starzenie się: kobieca aktywność seksualna, wypadanie narządów miednicy i nietrzymanie moczu. Pol. Prz. NaukZdr. 2014; 1: 25-28.

6. Jarząbek-Bielecka G, Plagens-Rotman K, Kędzia W, et al. The importance of DHEA in sexual health during menopause. Farm. Pol. 2020; 9: 537-540.

7. Jarząbek-Bielecka G, Bielecki M, Buks J, et al. Operational and conservative methods of dealing in gynecology. Pol. Prz. Nauk Zdr. 2015; 2: 89-92.

8. Yong SB, Daman JJ, Bony LG. Vaginal paravaginal repair; one year outcomes. Am. J. Obstet. Gynecol. 2001; 185(6): 1360-1367.

9. Cervigni $M$, Natale $F$. The use of synthetics in treatment of pelvic organ prolapse. Curr Opin. Urol. 2001; 11: 429-435.

10. Arunkalaivanan AS, Barington JW. Randomized trial of porcine dermal sling Pelvicol (implant) vs tension free vaginal tape (TVT) in the surgical treatment of stress incontinence: a guestionnaire - based study. Int. Urogynecol. J. Pelvic. Floor Dysfunct. 2003; 14:.17-23.
11. Stadnicka G, Łepecka-Klusek C, Pilewska-Kozak AB. Pelvic floor muscle disorders among women 95 Pelvic floor muscle disorders and women's quality of life. Prog. Health Sci. 2016; 1: 95-101.

12. Wagenlehner FMT, Bschleipfer T, Liedl B, et al. Surgical Reconstruction of Pelvic Floor Descent: Anatomic and Functional Aspects. Urol. Int. 2010; 84:1-9. D0I: $10.1159 / 000273458$.

13. Beckley I, Harris N. Pelvic organ prolapse: a urology perspective. Journal of Clinical Urology. 2013; 2: 68-76.

14. Veit-Rubin N, Dubuisson J, Ford AJ, et al. Burch colposuspension. Neurourol. Urodyn. 2019; 38(2): 553-562. doi: 10.1002/nau.23905.

15. Nerli RB, Kumar Ajay G, Koura A, et al. Transobturator vaginal tape in comparison to tension-free vaginal tape: A prospective trial with a minimum 12 months follow-up. Indian. J. Urol. 2009; 25(3): 321-325. doi: 10.4103/0970-1591.56183.

16. Costantini E, Mearini L, Lazzeri $M$, et al. Laparoscopic versus abdominal sacrocolpopexy: a randomized. Control. Trial, J. Urol. 2016; 196(1): 159-165.

17. Martin A. Ultrasound imaging of paravaginal defect repair. Ultrasound Obstet. Gynecol. 2002; 19: 496-500.

18. Jarząbek-Bielecka G, Buks J, Pisarska-Krawczyk M, et al. Health promotion and statics genital disorders. Pol. Prz. Nauk Zdr. 2015; 2: 97-102.

19. McRorie JW Jr, Fahey GC Jr, Gibb RD, Chey WD. Laxative effects of wheat bran and psyllium: Resolving enduring misconceptions about fiber in treatment guidelines for chronic idiopathic constipation. J. Am. Assoc. Nurse Pract. 2019; 11: 21. doi: 10.1097/JXX.0000000000000346.

20. Mazloom K, Siddiqi I, Covasa M. Probiotics: How Effective Are They in the Fight against Obesity? Nutrients. 2019; Jan 24;11(2). pii: E258. doi: 10.3390/nu11020258.

21. Jarde A, Lewis-Mikhael AM, Moayyedi P, et al. Pregnancy outcomes in women taking probiotics or prebiotics: a systematic review and meta-analysis. BMC Pregnancy Childbirth. 2018; 18: 14.

22. Kirihara N, Kamitomo M, Tabira T, et al. Effect of probiotics on perinatal outcome in patients at high risk of preterm birth. J. Obstet. Gynaecol. Res. 2018; 44: 241-247.

23. Xie HY, Feng D, Wei DM, et al. Probiotics for vulvovaginal candidiasis in non-pregnant women. Probiotics for vulvovaginal candidiasis in non-pregnant women. Cochrane Database Syst. Rev. 2017; 11: CD010496.

24. Tan H, Fu Y, Yang C, Ma J. Effects of metronidazole combined probiotics ove metronidazole alone for the treatment of bacterial vaginosis: a metaanalysis of randomized clinical trials. Arch. Gynecol. Obstet. 2017; 295: 1331-1339.

25. Ma L, Su J, Su Y, et al. Probiotics administered intravaginally as a complementary therapy combined with antibiotics for the treatment of bacterial vaginosis: a systematic review protocol. BMJ Open. 2017; 7: e019301.

26. Reid G, Younes JA, Van der Mei HC, et al. Microbiota restoration: natural and supplemented recovery of human microbial communities. Nat. Rev. Microbiol. 2011; 9: 27-38.

27. Tuohy KM, Conterno L. Gasperotti M, Viola R. Up-regulating the human intestinal microbiome using whole plant foods polyphenols, and/or fiber. J. Agric. Food Chem. 2012; 60: 8776-8782.

28. Bustamante M, 0omah BD, Oliveira WP, et al. Probiotics and prebiotics potential for the care of skin, female urogenital tract, and respiratory tract. Folia Microbiol (Praha). 2019; Nov: 26. doi: 10.1007/s12223-019-00759-3. [Epub ahead of print].

29. Rocca Rossetti S. Arch Ital Urol Androl. 2016 Mar 31; 88(1): 28-37. doi: 10.4081/ aiua.2016.1.28.Functional anatomy of pelvic floor.

30. Nygaard IE, Shaw JM, Bardsley T, Egger MJ. Lifetime physical activity and pelvic organ prolapse in middle-aged women. Am. J. Obstet. Gynecol. 2014 May; 210(5): 477.e1-477.e12. doi:10.1016/j.ajog.2014.01.035.

Manuscript received: 10.11 .2020

Manuscript accepted: 26.11.2020

Translation: Małgorzata Mizgier 